\title{
A test on within-individual changes in risk-taking behaviour due to experience to predation in the Collared Flycatcher (Ficedula albicollis)
}

\author{
Katalin KrenhardT ${ }^{1 *}$, Gábor Markó ${ }^{1,2,3}$, Eszter SzÁsz ${ }^{1}$, Mónika \\ JABLONSZKY ${ }^{1}$, Sándor ZsEBöK ${ }^{1}$, János TÖRÖK ${ }^{1}$ \& László Zsolt \\ GARAMSZEGI $^{4}$
}

Received: February 18, 2016-Accepted: May 25, 2016

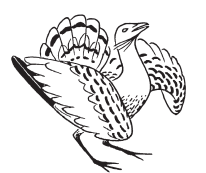

Katalin Krenhardt, Gábor Markó, Eszter Szász, Mónika Jablonszky, Sándor Zsebők, János Török \& László Zsolt Garamszegi 2016. A test on within-individual changes in risk-taking behaviour due to experience to predation in the Collared Flycatcher (Ficedula albicollis). - Ornis Hungarica 24(1): $115-127$

\begin{abstract}
Summary Different experiences from the past may have influence on individual's behaviour through feedback mechanisms that can weaken or preserve the within-individual consistency of behavioural traits. Here, we aimed to find evidence for such feedback mechanisms that may operate on risk-taking behaviour via the effect of former experience to potential predation events in male Collared Flycatchers (Ficedula albicollis). We predicted that risk-taking of males would decrease after experiencing a predator's attack in previous breeding seasons (negative feedback). We assessed risk-taking by flight initiation distance (FID) that is the distance at which an individual flees from an approaching predator, which was estimated for 234 individuals from different breeding seasons. Information on predation experience (i.e. occurrence of nest predation, the incidence of capture by human observers) was available from our long-term database on individual life histories. In a horizontal approach, we found no difference in FID when comparing males with former experience to predation with males naive to predators. A longitudinal approach relying on the repeated tests of the same individuals from different years yielded analogous results, we could not show a significant change in the risk-taking behaviour of the males as a consequence of experience to predation in past years. However, we found that individuals systematically took less risk over the years, which might be a consequence of acquiring general experience with age.
\end{abstract}

Keywords: feedback mechanisms, predation, human handling, flight initiation distance

Összefoglalás A különböző múltbéli tapasztalatok visszacsatolásos mechanizmusokon keresztül hatással lehetnek az egyedek személyiségére, mert az ilyen visszajelzések gyengíthetik vagy konzerválhatják az egyedek viselkedésének konzisztenciáját. Kutatásunkban visszacsatolásos mechanizmusok létezésére kerestünk bizonyítékot a múltbéli predációs események egyedek kockázatvállaló viselkedésére gyakorolt hatásának vizsgálatával hím örvös légykapók (Ficedula albicollis) esetén. Predikciónk szerint a korábbi predációs tapasztalattal rendelkező hímek kockázatvállalása csökken a predációs eseményt követő költések során (negatív visszacsatolás). Az egyedek kockázatvállaló viselkedését a menekülési távolsággal (FID, Flight Initiation Distance) becsültük meg, ami azt a távolságot jelenti, amelynél a madár elrepül az őt megközelítő ragadozó elől. Az egyedek predációs múltjának feltérképezéséhez a hosszú távú költési adatbázisunkat használtuk. Összehasonlítva a predációs múlttal rendelkező és nem rendelkező hímek FID adatait (horizontális megközelítés), eredményeink alapján a predációs tapasztalattal bíró egyedek és naiv társaik kockázat vállalásában nem tudtunk különbséget kimutatni. Az egyedek különböző évekböl származó ismételt mérésén alapuló vizsgálatai (longitudinális megközelítés) esetében sem tudtunk szignifikáns különbséget kimutatni a predációs tapasztalat alapján elkülönülő egyedek kockázatvállaló viselkedése között. Azonban azt találtuk, hogy az egyedek szisztematikusan kisebb kockázatot vállalnak az évek múlásával, ami a korral történő általános tapasztalatszerzésnek lehet a következménye.

Kulcsszavak: visszacsatolásos mechanizmusok, predáció, emberi kezelés, menekülési távolság 


\begin{abstract}
${ }^{1}$ Behavioural Ecology Group, Department of Systematic Zoology and Ecology, Eötvös Loránd University, 1117 Budapest, Pázmány Péter sétány 1/C, Hungary, e-mail: kicsi.buborek@gmail.com

${ }^{2}$ Department of Plant Pathology, Szent István University, 1118 Budapest, Ménesi út 44., Hungary

${ }^{3}$ MTA-ELTE-MTM Ecology Research Group, Biological Institute, Eötvös Loránd University, 1117 Budapest, Pázmány Péter sétány 1/C, Hungary

${ }^{4}$ Department of Evolutionary Ecology, Estación Biológica de Doñana-CSIC, c/Americo Vespucio s/n, 41092 Seville, Spain

*corresponding author
\end{abstract}

\title{
Introduction
}

In the field of behavioural ecology, recent studies have discovered that there are consistent differences in behaviour among individuals within a population. Such variations describe animal personality, and have important evolutionary implications (Bell 2007). Behaviour can be considered consistent within an individual if it reacts similarly and displays more or less the same behavioural responses in different temporal and environmental contexts (Sih et al. 2004, 2012). However, behaviours can also vary within individuals, and such flexible responses could help animals to cope adaptively with the changing environmental conditions (behavioural plasticity, Dingemanse et al. 2009).

Animal personality and behavioural plasticity could be influenced by experiences through feedback mechanisms (Stankowich \& Blumstein 2005). The future state of the individual could be affected by its current behaviour through experience, either in a negative or a positive way by further weakening or preserving the consistency of the given behaviour (Luttbeg \& Sih 2010). For instance, if an individual is bolder, it may show more courage to protect the nest from an approaching predator. By defending the nest successfully, the individual could increase its reproductive success which permits the maintenance of the bold behaviour towards other predators (positive feedback, Sih 2011). However, being bolder may lead to injuries when defending the nest from predators thus jeopardizing the future survival of the offspring and the individual as well (negative feedback). Therefore, relying on past experiences, an individual has to optimise the expression of its particular behaviour in order to find the balance between the benefits and the costs in predatory situations.

In behavioural ecology, different behavioural traits can be classified into categories according to the underlying ecological challenge (Reale et al. 2007). One of these major domains is the risk-taking domain, which defines how individuals react in a predatory or in other risky situations, and it bears with a strong evolutional and ecological significance. Risk-taking behaviour has been shown to have fitness consequences between individuals (Smith \& Blumstein 2008). Bolder individuals in various species have higher reproductive success than their shier conspecifics, but they have a shorter lifespan (Reale et al. 2000, Korhonen et al. 2001). Like other behavioural traits, risk-taking behaviour can be consistent and plastic at the same time within individuals. Individuals depict behavioural reaction norms, which show how behaviour changes within individuals along an environmental gradient. The slope of these reaction norms indicates plasticity, while a systematic difference in their intercepts signifies consistent behavioural differences among 
individuals. The most common influential factors that have been identified to trigger plastic risk-taking behaviour are predation (e.g. density of predators, Brown et al. 2005), the phase of the breeding season (Montgomerie \& Weatherhead 1988) and the physiological condition of the individual such as parasite infections (Møller \& Nielsen 2007) or testosterone level (Martins et al. 2007). As risk-taking behaviour can show remarkable plasticity, it can be hypothesized that former experiences induced by different stimuli influence the future risk-taking strategies of individuals through feedback mechanisms. Positive experiences may facilitate the maintenance of the current risk-taking behaviour as the individual can benefit from it, while experiences decreasing future reproductive success will alter the individual's risk-taking decisions.

Individual risk-taking can be measured as flight initiation distance (FID, Ydenberg \& Dill 1986, Blumstein 2003) in different taxa, which is an inverse scale quantifying the distance at which a prey individual starts to flee when a predator is approaching. Collared Flycatchers (Ficedula albicollis) are proven to be a good model species to study risk-taking behaviour, as FID varies at the between-individual level, and individual-specific estimates of FID correlate with other behavioural traits like aggression in a Hungarian population (Garamszegi et al. 2015). In contrast to considerable within-year repeatability, between-year repeatability appeared to be low, which raises the question whether individuals can adaptively change their risk-taking behaviour from one year to the next, and such plasticity in FID can be attributed to former experiences to predation.

The aim of the present study was to explore the relationship between the risk-taking behaviour of male flycatchers and former experience to predation based on two different approaches (Gil et al. 2001, Van De Pol \& Verhulst 2006). First, in a horizontal approach, we compared FID across individuals based on the presence or absence of former experience to predation. Such a horizontal approach, based on individual-specific (phenotypic) mean estimates does not allow discriminating the within-individual and between-individual effects statistically (Dingemanse \& Dochtermann 2013, Garamszegi et al. 2013). Therefore, second, we also applied a longitudinal approach, in which we compared FID within the same males that were tested more than once during the study years, prior and after a predation event. We considered two stressful stimuli that can potentially contribute to the experience to predation. We distinguished i) whether individuals experienced any predation event at their nests during their life; and ii) whether individuals experienced any stress due to capturing and handling by humans during the standard ringing protocols. For the horizontal approach, we predicted that if former experience works as negative feedback, then males with experience to any of the two stimuli would take less risk compared to their naive conspecifics, so their FID would be higher. In case of the longitudinal analysis, we predicted that males experiencing nest predation or human handling between the two behavioural tests will generally take less risk in the second test compared to naive males. 


\section{Material and Methods}

\section{Study area and model species}

Our research was carried out in the Pilis Mountains, Hungary. The study area is within an unmanaged, mainly oak-dominated, continuous woodland, which is protected by the Duna-Ipoly National Park. There are around 800 nest boxes on the study plots, where our model species, the Collared Flycatcher breeds together with other hole-nesting passerines such as the Great Tit (Parus major) and the Blue Tit (Cyanistes caeruleus). The populations of these small passerine birds have been regularly monitored since 1983 (Török \& Tóth 1988). The Collared Flycatcher nests naturally in tree cavities, and is a long-distance migratory species arriving to our breeding site from Africa in the middle of April. Male Collared Flycatchers arrive earlier than females, and compete for the best territories. Males and females do not differ in size, but they show sexual dimorphism in terms of feather colouration. Both sexes bear white wing patches, which are condition-dependent ornaments signalling individual quality (Török et al. 2003, Hegyi et al. 2008), while only males have a white forehead patch, which also has a signal function. It signals the physical condition of the individual, and it plays an important role in mate choice (Hegyi et al. 2010). Males with bigger forehead patches tend to find a mate earlier during courtship than males with smaller forehead patches.

\section{Field work}

For this study, we used data from nine years, from 2007 to 2015, in which we assessed the risk-taking behaviour of males by measuring FID (Garamszegi et al. 2009). We collected data only from males, because during courtship only their behaviour can be assessed around the nest-box, while a similar procedure cannot be established for females. The assessment of risk-taking started with provoking the focal male into a territorial dispute by placing a decoy male flycatcher in a small cage as an intruder on the focal male's territory (by doing so we achieved that each focal bird was engaged in the same background behavioural activity before assessing FID). When the focal male was observed on the stimulus cage, the observer began to approach it from about $30 \mathrm{~m}$, until it took notice of the presence of the potential predator, and flew away from the decoy's cage. If the resident male returned to continue the territorial dispute within 1 minute, the experimenter proceeded walking towards the focal bird. The process was repeated up to the point where the focal male did not come back anymore to the cage within a minute (all individuals returned at least once). FID was measured by the number of steps (approx. $1 \mathrm{~m}$ ) between the decoy's cage and the last position of the observer where the male did not return. After the behavioural tests, we caught the males at their nest boxes by using conventional spring traps and ringed them for long-term identification.

We considered two different stressful stimuli as components of predation experience in the analyses. In one hand, we specified whether the tested individual suffered nest predation (former experience to predators). We considered a nest predated if any of the following 
events were detected during the standard nest box monitoring between egg laying and chick-feeding period: nest structure was disarranged and/or nest material was pulled out of the nest box and/or torn feathers covered the surroundings. The most common nest predators of flycatchers are stoats, weasels, martens and woodpeckers (Lundberg \& Alatalo 1992). On the Hungarian study site, flycatcher nests are mainly predated by small mammalian nest predators such as weasels, martens and cats. On the other hand, we defined whether the male flycatcher experienced any incidence of human handling prior to the behavioural test. Every male wearing a ring for identification was considered experienced to handling, as males always have to be captured for ringing. We used our long-term database to determine the history of these events within each male's lifetime.

\section{Statistical approaches}

We studied the relationship between experience to predation (true predator or human handling) and risk-taking behaviour using two different approaches. In the horizontal approach, we aimed to capture the presence of the feedback mechanism by comparing FID of males with former experience to predation or human handling to FID estimates of males naive to predators or humans, sampling the whole population. In this case, we could utilize a larger sample size $(\mathrm{N}=234)$. In the longitudinal approach, we focused on males, for which we had repeated FID estimates from different years. In this sample, we determined how the FID value changed between the two tests of the same individuals. Furthermore, we assessed whether this change differed between experienced and naive males with respect to predation. In the case of experience to nest predation, the sample size was 16, while the sample size was 19 when the former experience was related to human handling. In these longitudinal tests, we used different groups of individuals for each type of experience (naive to either nest predation or human handling), as control reference ( $\mathrm{N}=10$ and $\mathrm{N}=7$ respectively).

We used general linear mixed models to determine the possible role of a life-threatening experience on individual risk-taking decisions. We used the log10-transformed form of FID in all statistical analysis to ensure the normal distribution of model residuals. We run three different statistical models. In the horizontal approach, the model contained the experiences to predation and human handling, the age of the individuals and the day when the test was carried out as predictors. We included random factors in the model to control for the hierarchical structure of the data. We used the same decoy bird in several experiment to provoke aggressive behaviour before the assessment of FID, thus we used the ring number of decoy males as a random factor ( $\mathrm{N}=36$ decoy males). In a few cases, we had multiple data from the same individual, thus we also entered the ring number of tested males to control for pseudoreplication (note that within-individual and temporal order effects are tested in the longitudinal model). Finally, we considered observer and year effects to partition variance components in the model via the appropriate random factors. In our dataset, there were several naive males not experiencing any predation events $(\mathrm{N}=211)$ that could all be used as controls, but these controls could have different association with males experiencing nest predation. We discriminated between historical and true controls (Kramer \& Font 2015) based on whether they were tested on the same day as the experienced males. To achieve this we 
created a new binary variable, named 'day code', characterising whether naive individuals in the analysis were tested on the same day or not with regard to the experienced males. This variable was used as random factor to model historical and true controls. In the longitudinal approach, we defined two models based on the type of experience, which contained the experience itself, the relative order of the two behavioural tests, and the age of the males as predictors. We entered the same random effects in these models than in the previous one.

We used likelihood ratio tests to determine $\chi^{2}$ and $p$-values corresponding to particular predictors (achieved by comparing models including and lacking the respective predictor). As the main question of our research was to investigate whether former experience has any effect on the risk-taking behaviour of the males when controlling for the effects of potentially interfering factors, primarily we were interested in the full model and accordingly we did not perform further model selection for the fixed effects (we note however that if we exclude non-significant terms from our models, the main findings of the study do not change with respect to those we report below). Concerning the random effects, we simplified our final models by excluding terms that had lower variances than 0.001 .

Before interpreting the model outputs, we performed appropriate model diagnostics to determine whether all the necessary model assumptions were valid by checking the normal distribution of model residuals with q-q plots, checking the normality of the random effects and inspecting multicollinearity by calculating VIF (O'Brien 2007). All statistical analyses were performed in R statistical environment (R Development Core Team 2015) using 'Ime4' package (Bates et al. 2015).

\section{Results}

\section{Horizontal approach}

The results of the statistical model built to test the effects of former experience on risk-taking behaviour are given in Table 1. We found no significant difference in FID between males with and without former experience to predation. Males experiencing nest predation at least once in their lifetime did not take less risk during the tests than their conspecifics that were naive to predators. The experience to human handling also had no significant effect on FID. Ringed males did not tend to be more cautious than males without experience to humans. Similarly, the date of the test had no significant effect on risk-taking behaviour. On the other hand, the FID estimates depended significantly on the age of the individuals, older males taking less risk than younger conspecifics. We excluded the ring of the tested males, the observer and the day code from the random factors because of their low variance $(<0.001)$.

\section{Longitudinal approach}

Studying the relationship between experience to predation and risk-taking behaviour of repeatedly tested males, we found no significant effect of former experience on FID (Figure 1, 


\section{J. Török \& L. Zs. Garamszegi}

\begin{tabular}{|l|c|c|c|c|}
\hline Predictor variables & $\boldsymbol{\beta ( S E )}$ & $\mathbf{t}$ & LRT X2 & P \\
\hline experience to predation & $0.031(0.069)$ & 0.447 & 0.185 & 0.667 \\
\hline experience to handling & $0.019(0.045)$ & 0.265 & 0.094 & 0.759 \\
\hline date & $0.0003(0.004)$ & 0.073 & 0.001 & 0.977 \\
\hline age & $\mathbf{0 . 0 3 6 ( 0 . 0 1 7 )}$ & $\mathbf{2 . 1 5 8}$ & $\mathbf{4 . 8 2 6}$ & $\mathbf{0 . 0 2 8}$ \\
\hline
\end{tabular}

\begin{tabular}{|l|c|c|}
\hline Random effects & Variance & $\begin{array}{c}\text { Standard } \\
\text { deviation }\end{array}$ \\
\hline male decoy & 0.004 & 0.066 \\
\hline year & 0.005 & 0.070 \\
\hline residual & 0.077 & 0.278 \\
\hline
\end{tabular}

Table 1. The results of the horizontal analysis representing the relationship between flight initiation distance (FID) and the examined predictor variables: the experience to predation and human handling, the day when the tests were carried out and the age of the males. The random factors in this model were the ring of the male decoys and the year when the tests were carried out. P-values are shown based on likelihood ratio tests (LRT). $\mathrm{N}=234$

1. táblázat A múltbéli tapasztalatok és a menekülési távolság (FID) közötti kapcsolat horizontális megközelítés esetén. A modellben magyarázó változóként szerepel a predációs múlt, az emberi kezelésből származó tapasztalat, a tesztek dátuma (nap) és a hímek kora. Random változóként a csali hím gyűrűszáma és a kísérlet éve szerepel. A P-értékek a likelihoodhányados tesztekből (likelihood ratio test) származnak. $\mathrm{N}=234$

Table 2). However, the order of the tests was a significant predictor of risk-taking in case of experience to predation with increasing FID values from year to year. In this model, the FID estimates did not depend significantly on the age of the individuals. We excluded the ring of the decoy male, the year, the observer and the day code as their variance was lower than 0.001 . The results of the other model studying experience to human handling showed that males experiencing human handling did not take significantly less risk than their conspecifics without experience (Figure 2, Table 3). Neither the order of the tests, nor the age of the individuals correlated significantly with the FID estimates. We excluded the ring of the decoy male, the year, the observer and the day code because of their low variance $(<0.001)$.

\section{Discussion}

In this study, we investigated the relationship between former experiences to potentially life-threatening stimuli and risk-taking behaviour in male Collared Flycatchers. The main hypotheses were that individuals with experience to predation or human handling would take less risk than their naive conspecifics. We found no evidence that former experience to predation had any effect on the risk-taking decisions, neither in the horizontal, nor in the longitudinal approaches. When studying the effect of experience to human handling, we got the same results as mentioned above. However, in the horizontal analysis the risk-taking behaviour of the males depended on their age. 


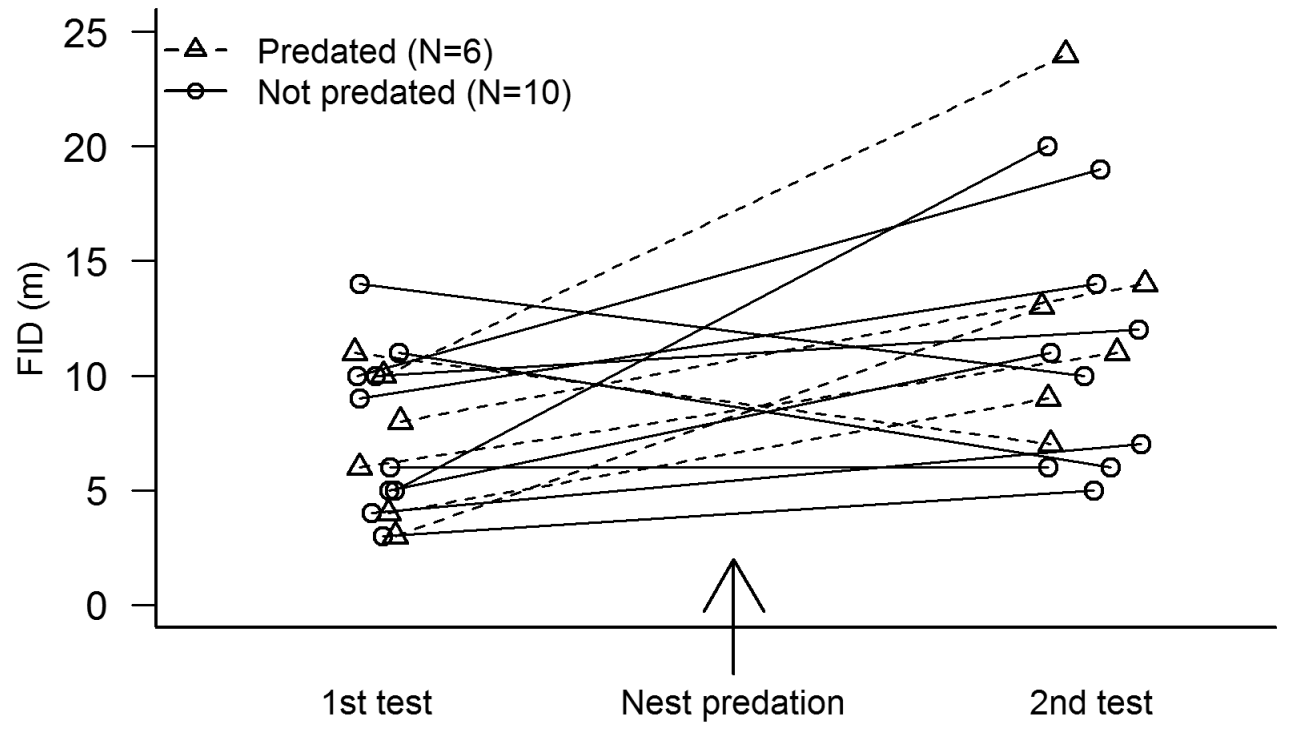

Figure 1. The changes in the flight initiation distance (FID) of flycatcher males that were repeatedly tested in two consecutive years. The triangles and dashed lines represent males with experience to predation, while the circles and continuous lines describe individuals naive to predators

1. ábra A FID változása a két különböző évben elvégzett teszt között. A predációs múlttal rendelkező egyedeket háromszöggel és szaggatott vonallal, a predációs múlttal nem rendelkező egyedeket pedig körrel és folytonos vonallal jelöltük

\begin{tabular}{|l|c|c|c|c|}
\hline Predictor variables & $\boldsymbol{\beta ( S E )}$ & $\mathbf{t}$ & LRT X2 & P \\
\hline experience to predation & $0.037(0.090)$ & 0.406 & 0.188 & 0.664 \\
\hline order & $\mathbf{0 . 1 8 1 ( 0 . 0 7 9 )}$ & $\mathbf{2 . 3 0 2}$ & $\mathbf{4 . 4 4 6}$ & $\mathbf{0 . 0 3 5}$ \\
\hline age & $0.011(0.028)$ & 0.389 & 0.229 & 0.632 \\
\hline
\end{tabular}

\begin{tabular}{|l|c|c|}
\hline Random effects & Variance & $\begin{array}{c}\text { Standard } \\
\text { deviation }\end{array}$ \\
\hline ring & 0.012 & 0.111 \\
\hline residual & 0.034 & 0.184 \\
\hline
\end{tabular}

Table 2. The results of the longitudinal analysis representing the relationship between flight initiation distance (FID) and the examined predictor variables: the experience to predation, the chronological order of the tests and the age of the males. The random factor in this model was the ring of the tested males. P-values are shown based on likelihood ratio tests (LRT). $\mathrm{N}=16$

2. táblázat A predációs múlt és a menekülési távolság (FID) közötti kapcsolat az egyedek ismételt mérése esetén. A modellben magyarázó változóként szerepel a predációs tapasztalat, a tesztek sorrendje és a hímek kora. Random változóként a tesztelt hím azonosítója szerepel. P-értékek a likelihood-hányados tesztekből (likelihood ratio test) származnak. N=16 
K. Krenhardt, G. Markó, E. Szász, M. Jablonszky, S. Zsebök,

J. Török \& L. Zs. Garamszegi

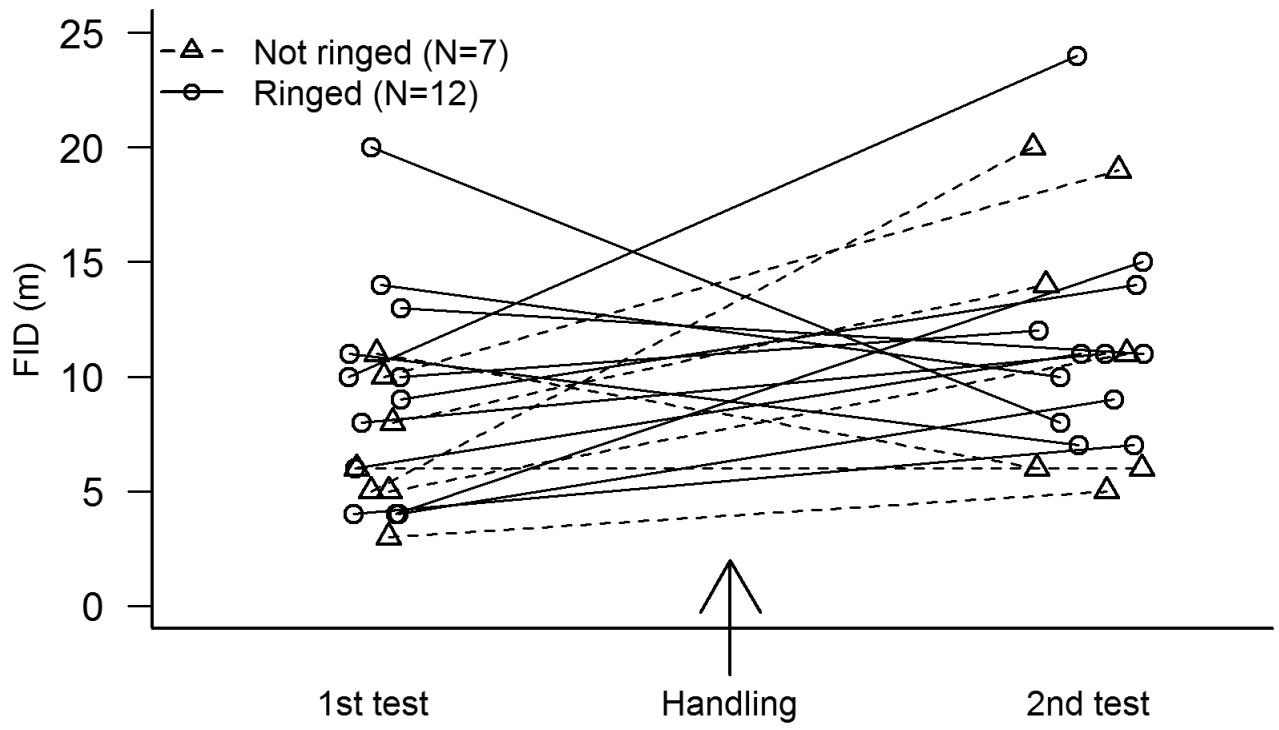

Figure 2. The changes in the flight initiation distance (FID) of flycatcher males that were repeatedly tested in two consecutive years. The triangles and dashed lines represent naive males with no experience to human handling, while the circles and continuous lines describe experienced individuals

2. ábra A kockázatvállaló viselkedés változása a két különböző évben elvégzett teszt között. A gyűrűvel nem rendelkező egyedeket háromszöggel és szaggatott vonallal, a gyűrüvel rendelkező egyedeket pedig körrel és folytonos vonallal jelöltük

\begin{tabular}{|l|c|c|c|c|}
\hline Predictor variables & $\boldsymbol{\beta ( S E )}$ & $\mathbf{t}$ & LRT X2 & P \\
\hline experience to handling & $0.135(0.077)$ & 1.738 & 3.263 & 0.071 \\
\hline order & $0.127(0.074)$ & 1.722 & 3.129 & 0.077 \\
\hline age & $-0.0004(0.023)$ & -0.018 & 0.0002 & 0.988 \\
\hline
\end{tabular}

\begin{tabular}{|l|l|l|}
\hline Random effects & \multicolumn{1}{|c|}{ Variance } & \multicolumn{1}{|c|}{$\begin{array}{c}\text { Standard } \\
\text { deviation }\end{array}$} \\
\hline ring & 0.001 & 0.028 \\
\hline residual & 0.037 & 0.193 \\
\hline
\end{tabular}

Table 3. The results of the longitudinal analysis showing the relationship between flight initiation distance (FID) and the examined predictor variables, the former experience to human-handling, the chronological order of the tests and the age of the males. In this model the random factor was the ring of the tested males. P-values are shown based on likelihood ratio tests (LRT). $\mathrm{N}=19$

3. táblázat Az emberi megfogásból származó tapasztalat és a menekülési távolság (FID) közötti kapcsolat a longitudinális elemzés esetén. A modellben magyarázó változóként szerepel a múltbéli tapasztalat emberrel, a tesztek sorrendje és a hímek kora. Random változóként a tesztelt hím azonosítója szerepel a modellben. P-értékek a likelihood-hányados tesztekből (likelihood ratio test) származnak. $\mathrm{N}=19$ 
In the horizontal approach, we investigated the between-individual component of the phenotypic change in risk-taking behaviour. Using all available data, we could operate with a bigger sample size and thus we were able to search for patterns in risk-taking behaviour in general based on former experience. As the horizontal approach could not give information about within-individual changes, we applied a longitudinal approach to separate the between- and within-individual effects of the risk-taking behaviour. In this case, we could focus on the within-individual changes but we had to operate with a smaller sample size. Despite of the two different statistical approaches, neither proved that a negative feedback mechanism via former experience to predation or human handling would mediate the risk-taking behaviour of male flycatchers, as individual experience to any of the two stimuli did not predict FID estimates.

For the lack of any effect of the experiences on risk-taking behaviour, we suggest the following explanations. In case of experience to predation, a possible reason behind our observations may be that the influence of a single predation event (that we considered in our study) is too small to be detected in our sample by using observational data instead of performing targeted experiments. For example, one event of nest predation can have no detectable influence on the risk-taking decisions, because the males may need repeated stimuli to alter their behaviour as it was shown in mice (Kinsey et al. 2007). Additionally, experienced males may not necessarily take less risk than their conspecifics naive to predation but may also increase risk-taking (Oosten et al. 2010). Based on our observations, predators do not always destroy the whole nest, which could be a consequence of successful nest defence of the focal male. Saving part of the nestlings could encourage the male to take greater risk next time when encountering a predator to save even more of its offspring. Note that in the longitudinal approach, we operated with a relatively small sample size, so it remains plausible that if we could collect more data from repeatedly tested males in the next few years, the relationship between risk-taking behaviour and experience to predation would turn significant.

We note that some of the non-significant effects in relation to human handling involved biologically meaningful tendencies that fall in the expected direction (which were close to statistical significance). This may suggest that we would need a larger sample size by repeatedly testing the same male in different years to make strong conclusions about these effects. In any case, this also implies that our analysis for human handling may partially suffer from insufficient statistical power. As an explanation, it is possible that one encounter with humans at the ringing procedure is not a sufficient stimulus to alter individual risk-taking decisions, just like in case of real predation. Another reason for the failure of finding a significant effect is that males were ringed far from their nest boxes at our field station, and the ringing process did not have serious impact on the birds, thus such an experience may serve as a weaker stimulus. It is possible that the stress connected with the ringing procedure was not sufficient enough to alter considerably the future risk-taking behaviour of ringed males.

We found a significant relationship between the FID and the age of male flycatchers in the horizontal approach, similarly to another study (Jablonszky et al. 2016 submitted) showing that older individuals have higher FID values and are more cautious than their younger conspecifics. Moreover when studying the effect of the experience to predation in 
the longitudinal approach, we were able to show within-individual changes in risk-taking behaviour, individuals taking less risk during the second than in the first tests. In the background of these observed patterns, the following causes may stand. The relationship between risk-taking decisions and age could be explained through the process of aging. With age, the physiology of the individual alters and its physical condition decreases (Vleck et al. 2011). For an older individual, it might be more important to pursue an energy saving strategy (Lecomte et al. 2010) thus avoiding acting bolder (Patrick et al. 2013). On the other hand, experiences collected through the years could stand in the background of the relationship as well (Dill 1974, Ydenberg \& Dill 1986). An older male may be more skilful detecting the approaching predator than its younger conspecifics, so it flees away earlier to avoid the rush (Blumstein 2010).

Furthermore, the results could also be mediated by effects due to aging or experience that are acting on aggression and not on risk-taking per se. In another study of our Hungarian population, a relationship has been shown between the aggressive behaviour and the age of male flycatchers. The latency of the first attack of the focal male on the cage of the stimulus male was shorter in yearlings than in adult individuals, which means that older individuals were less aggressive (Garamszegi et al. 2006). Huntingford and his colleagues (2012) showed a positive relationship between territorial aggression in the breeding season and risk-taking behaviour, aggressive Three-spined Stickleback (Gasterosteus aculeatus) males being significantly bolder than their unaggressive conspecifics. If aggression and risk-taking behaviour depends on each other in a positive way, and aggression decreases with age, than it is possible that risk-taking behaviour shows a similar decreasing pattern with age. Moreover, since we brought each individual into a territorial conflict prior to the assessment of FID, it is also plausible that older/experienced individuals that did not invest heavily into aggressive territorial defence could notice the approaching predator earlier. This mechanism mediated by the detection of the predator would also result in longer FID in older males.

In conclusion, we did not find any significant influence of former experience to predation or human handling on the risk-taking behaviour of male Collared Flycatchers, thus we were unable to provide support for a negative feedback mechanism. However, in the horizontal approach, we found an age effect indicating that older individuals decrease their risk-taking over the years, which might be a consequence of aging or experience.

\section{Acknowledgements}

We would like to thank the members of the Behavioural Ecology Group of Eötvös Loránd University for their help in the fieldwork. This study was supported by the Hungarian National Research, Development and Innovation Office (K-105517, K-115970, PD-115730) and the Consejo Superior de Investigaciones Científicas (Spain) (CGL2015-70639-P). We are grateful to the Pilis Park Forestry. 


\section{References}

Bates, D., Maechler, M., Bolker, B. M. \& Walker, S. C. 2015. Fitting linear mixed-effects models using Lme4. - Journal of Statistical Software 67: 1-48.

Bell, A. M. 2007. Future directions in behavioural syndromes research. - Proceedings of the Royal Society B, Biological Sciences 274: 755-761. DOI: 10.1098/rspb.2006.0199

Blumstein, D. T. 2003. Flight-initiation distance in birds is dependent on intruder starting distance. - Journal of Wildlife Management 67: 852-857. DOI: $10.2307 / 3802692$

Blumstein, D. T. 2010. Flush early and avoid the rush: a general rule of antipredator behaviour? - Behavioral Ecology 21: 440-442. DOI: 10.1093/beheco/arq030

Brown, C., Jones, F. \& Braithwaite, V. 2005. In situ examination of boldness-shyness traits in the Tropical Poeciliid, Brachyrhaphis episcopi. - Animal Behaviour 70: 1003-1009. DOI: 10.1016/j. anbehav.2004.12.022

Dill, L. M. 1974. The escape response of the Zebra Danio (Brachydanio rerio) II. The effect of experience. - Animal Behaviour 22: 723-730.

Dingemanse, N. J. \& Dochtermann, N. A. 2013. Quantifying individual variation in behaviour: mixed-effect modelling approaches. - Journal of Animal Ecology 82: 39-54. DOI: 10.1111/13652656.12013

Dingemanse, N. J., Van Der Plas, F., Wright, J., Reale, D., Schrama, M., Roff, D. A., Van Der Zee, E. \& Barber, I. 2009. Individual experience and evolutionary history of predation affect expression of heritable variation in fish personality and morphology. - Proceedings of the Royal Society B, Biological Sciences 276: 1285-1293. DOI: 10.1098/rspb.2008.1555

Garamszegi, L. Z., Markó, G., Szász, E., Zsebők, S., Azcarate, M., Herczeg, G. \& Török, J. 2015. Among-year variation in the repeatability, within- and between-individual, and phenotypic correlations of behaviors in a natural population. - Behavioral Ecology and Sociobiology 69: 2005-2017. DOI: 10.1007/s00265-015-2012-z

Garamszegi, L. Z., Markó, G. \& Herczeg, G. 2013. A meta-analysis of correlated behaviors with implications for behavioral syndromes: relationships between particular behavioral traits. - Behavioral Ecology 24: 1068-1080. DOI: 10.1093/beheco/art033

Garamszegi, L. Z., Eens, M. \& Török, J. 2009. Behavioural syndromes and trappability in free-living Collared Flycatchers, Ficedula albicollis.
-Animal Behaviour 77: 803-812. DOI: 10.1016/j. anbehav.2008.12.012

Garamszegi, L. Z., Rosivall, B., Hegyi, G., Szöllősi, E., Török, J. \& Eens, M. 2006. Determinants of male territorial behavior in a Hungarian Collared Flycatcher population: plumage traits of residents and challengers. - Behavioral Ecology and Sociobiology 60: 663-671. DOI: 10.1007/s00265-0060210-4

Gil, D., Cobb, J. L. S. \& Slater, P. J. B. 2001. Song characteristics are age dependent in the Willow Warbler, Phylloscopus trochilus. - Animal Behaviour 62: 689-694. DOI: 10.1006/anbe.2001.1812

Hegyi, G., Rosivall, B., Szöllősi, E., Hargitai, R., Eens, M. \& Török, J. 2008. Phenotypic plasticity in a conspicuous female plumage trait: information content and mating patterns. - Animal Behaviour 75: 977-989. DOI: 10.1016/j.anbehav.2007.08.009

Hegyi, G., Szöllősi, E., Jenni-Eiermann, S., Török, J., Eens, M. \& Garamszegi, L. Z. 2010. Nutritional correlates and mate acquisition role of multiple sexual traits in male Collared Flycatchers. Naturwissenschaften 97: 567-576. DOI: 10.1007/ s00114-010-0672-0

Huntingford, F., Tamilselvan, P. \& Jenjan, H. 2012. Why do some fish fight more than others? - Physiological and Biochemical Zoology 85: 585-593. DOI: $10.1086 / 668204$

Jablonszky, M., Szász, E., Markó, G., Török, J. \& Garamszegi, L. Z. 2016. The ability to escape and risk-taking behaviour in a Hungarian population of the Collared Flycatcher (Ficedula albicollis). submitted

Kinsey, S. G., Bailey, M. T., Sheridan, J. F., Padgett, D. A. \& Avitsur, R. 2007. Repeated social defeat causes increased anxiety-like behavior and alters splenocyte function in $\mathrm{C} 57 \mathrm{bl} / 6$ and $\mathrm{Cd}-1$ mice. - Brain, Behavior, and Immunity 21: 458-466. DOI: $10.1016 /$ j.bbi.2006.11.001

Korhonen, H., Niemelä, P. \& Siirilä, P. 2001. Temperament and reproductive performance in Farmed Sable. - Agricultural and Food Science in Finland 10: 91-97.

Kramer, M. \& Font, E. 2015. Reducing sample size in experiments with animals: historical controls and related strategies. - Biological Reviews of the Cambridge Philosophical Society DOI: 10.1111/ brv. 12237

Lecomte, V. J., Sorci, G., Cornet, S., Jaeger, A., Faivre, B., Arnoux, E., Gaillard, M., Trouvé, C., Besson, D., Chastel, O. \& Weimerskirch, H. 2010. Patterns 
of aging in the long-lived wandering albatross. Proceedings of the National Academy of Sciences of the United States of America 107: 6370-6375. DOI: $10.1073 /$ pnas.0911181107

Lundberg, A. \& Alatalo, R. V. 1992. The Pied Flycatcher. - T \& AD Poyser, London

Luttbeg, B. \& Sih, A. 2010. Risk, resources and statedependent adaptive behavioural syndromes. Philosophical Transactions of the Royal Society B, Biological Sciences 365: 3977-3990. DOI: 10.1098/rstb.2010.0207

Martins, T. L. F., Roberts, M. L., Giblin, I., Huxham, R. \& Evans, M. R. 2007. Speed of exploration and risk-taking behavior are linked to corticosterone titres in Zebra Finches. - Hormones and Behavior 52: 445-453. DOI: 10.1016/j.yhbeh.2007.06.007

Møller, A. P. \& Nielsen, J. T. 2007. Malaria and risk of predation: a comparative study of birds. - Ecology 88: 871-881. DOI: 10.1890/06-0747

Montgomerie, R. D. \& Weatherhead, P. J. 1988. Risks and rewards of nest defence by parent birds. Quarterly Review of Biology 63: 167-187. DOI: $10.1086 / 415838$

O'Brien, R. M. 2007. A caution regarding rules of thumb for variance inflation factors. - Quality \& Quantity 41: 673-690. DOI: 10.1007/s11135-0069018-6

Oosten, J. E., Magnhagen, C. \& Hemelrijk, C. K. 2010. Boldness by habituation and social interactions: a model. - Behavioral Ecology and Sociobiology 64: 793-802. DOI: 10.1007/s00265-0090896-1

Patrick, S. C., Charmantier, A. \& Weimerskirch, H. 2013. Differences in boldness are repeatable and heritable in a long-lived marine predator. - Ecology and Evolution 3: 4291-4299. DOI: 10.1002/ ece 3.748

Reale, D., Gallant, B. Y., Leblanc, M. \& Festa-Bianchet, M. 2000. Consistency of temperament in Bighorn Ewes and correlates with behaviour and life history. - Animal Behaviour 60: 589-597. DOI: $10.1006 /$ anbe. 2000.1530

Reale, D., Reader, S. M., Sol, D., Mcdougall, P. T. \& Dingemanse, N. J. 2007. Integrating animal temperament within ecology and evolution. - Biological Reviews of the Cambridge
Philosophical Society 82: 291-318. DOI: 10.1111/j.1469-185X.2007.00010.x

Sih, A. 2011. Effects of early stress on behavioral syndromes: an integrated adaptive perspective. - Neuroscience \& Biobehavioral Reviews 35: $1452-$ 1465. DOI: 10.1016/j.neubiorev.2011.03.015

Sih, A., Bell, A. \& Johnson, J. C. 2004. Behavioral syndromes: an ecological and evolutionary overview. - Trends in Ecology \& Evolution 19: 372378. DOI: 10.1016/j.tree.2004.04.009

Sih, A., Cote, J., Evans, M., Fogarty, S. \& Pruitt, J. 2012. Ecological implications of behavioural syndromes. - Ecology Letters 15: 278-289. DOI: 10.1111/j.1461-0248.2011.01731.x

Smith, B. R. \& Blumstein, D. T. 2008. Fitness consequences of personality: a meta-analysis. - Behavioral Ecology 19: 448-455. DOI: 10.1093/beheco/arm 144

Stankowich, T. \& Blumstein, D. T. 2005. Fear in animals: a meta-analysis and review of risk assessment. - Proceedings of the Royal Society B, Biological Sciences 272: 2627-2634. DOI: 10.1098/ rspb.2005.3251

Török, J. \& Tóth, L. 1988. Density dependence in reproduction of the Collared Flycatcher (Ficedula albicollis) at high population-levels. - Journal of Animal Ecology 57: 251-258. DOI: $10.2307 / 4776$

Török, J., Hegyi, G. \& Garamszegi, L. Z. 2003. Depigmented wing patch size is a condition-dependent indicator of viability in male Collared Flycatchers. - Behavioral Ecology 3: 382-388. DOI: 10.1093/beheco/14.3.382

Van De Pol, M. \& Verhulst, S. 2006. Age-dependent traits: a new statistical model to separate withinand between-individual effects. - American Naturalist 167: 766-773. DOI: 10.1086/503331

Vleck, C. M., Vleck, D. \& Palacios, M. G. 2011. Evolutionary ecology of senescence: a case study using Tree Swallows, Tachycineta bicolour. - Journal of Ornithology 152: 203-211. DOI: 10.1007/s10336-010-0629-2

Ydenberg, R. C. \& Dill, L. M. 1986. The economics of fleeing from predators. - Advances in the Study of Behavior 16: 229-249. DOI: 10.1016/s00653454(08)60192-8 